\title{
Impact of acadja fisheries on fish assemblages in Lake Nokoué, Benin, West Africa
}

\author{
C. Niyonkuru(1), P.A. Lalèyè((2) \\ Received May 28, 2010 / Reçu le 28 mai 2010 \\ Revised September 1, 2010 / Révisé le $1^{\mathrm{er}}$ septembre 2010 \\ Accepted September 15, 2010 / Accepté le 15 septembre 2010
}

\begin{abstract}
Key-words: impact, acadja fisheries, Lake Nokoué, Benin, ecological parameters, fish assemblages, rational management

Acadjas are artificial systems aimed at enhancing fish production by providing additional substrata for development of plants and animals upon which the fish will feed. This study aims to evaluate the impact of acadjas on fish assemblages and on conservation of the fish fauna diversity in Lake Nokoué in Benin. Between June 2003 and September 2004, experimental acadjas were installed and monitored. Fish samples were obtained from two areas of Lake Nokoué (Ganvié and Zogbo stations) within and without acadjas with the assistance of artisanal fishermen. Physico-chemical parameters were also measured inside and outside of the experimental acadjas in the same two stations. Twenty-five fish species belonging to 17 families were identified in acadjas out of a total of 51 species belonging to 34 families inventoried in 2001 at Lake Nokoué (i.e. 49\% of the specific richness of the ichthyofauna). Fifty-six percent of fish fauna caught in acadjas are estuarine forms and represent $78 \%$ of all estuarine forms of Lake Nokoué in 2001. The analysis of variance showed that the specific richness of the acadjas varied significantly according to the station $(p<0.05)$, with a high specific richness in Zogbo station where acadjas are less abundant. Acadjas are selective for some fish species such as cichlids which represent $95 \%$ of the total numeric abundance and contribute about $90 \%$ of the total fish biomass. The high densities of acadjas could contribute to the reduction of the richness of fish fauna. Rational management could consist of reorganizing the surface areas of Lake Nokoué by preserving areas for other fish species that do not colonize acadjas.
\end{abstract}

\section{ABSTRACT}

\section{RÉSUMÉ}

Impact des pêcheries en acadjas sur les assemblages de poissons du Lac Nokoué au Bénin, Afrique de l'Ouest

Mots-clés:
impact,
pêcheries
en acadjas,
paramètres
écologiques,
assemblage

\begin{abstract}
Les acadjas, ou parcs à poissons, sont des systèmes artificiels visant l'augmentation de la production de poisson en fournissant du substrat complémentaire pour le développement des plantes et animaux devant servir de nourriture aux poissons. Cette étude a pour objectif d'évaluer l'impact des acadjas sur les assemblages des poissons et la conservation de la diversité ichtyologique du lac Nokoué au Bénin. Ainsi, entre juin 2003 et septembre 2004, les acadjas expérimentaux ont été installés et suivis. Les échantillons de poissons ont été obtenus dans les deux stations
\end{abstract}

(1) Université du Burundi, Institut de Pédagogie Appliquée, BP 5223 Bujumbura, Burundi, cniyon@yahoo.fr

(2) Université d'Abomey-Calavi, Faculté des Sciences Agronomiques, Laboratoire d'Hydrobiologie et d'Aquaculture, 01 BP 526 Cotonou, Benin, laleyeph@yahoo.fr 
des poissons, gestion rationnelle
(Ganvié et Zogbo) du lac Nokoué à l'intérieur et à l'extérieur des acadjas à l'aide des pêcheurs artisanaux. Les paramètres physico-chimiques ont été également mesurés à l'intérieur et à l'extérieur des acadjas expérimentaux des mêmes stations. Au total, 25 espèces de poissons appartenant à 17 familles ont été identifiées à l'intérieur des acadjas sur un total de 51 espèces de poissons réparties en 34 familles inventoriées en 2001 au lac Nokoué. Cette richesse spécifique des acadjas représente ainsi $49 \%$ de la richesse spécifique de l'ensemble du lac Nokoué. Cinquante-six pourcent (56 \%) des espèces de poissons capturés dans les acadjas sont des formes estuariennes et représentent $78 \%$ de l'ensemble des formes estuariennes recensées au lac Nokoué en 2001. L'analyse de la variance a montré que la richesse spécifique des acadjas variait de façon significative avec les stations $(p<0,05)$, avec une grande richesse spécifique dans la station de Zogbo où les acadjas sont moins abondants. Les acadjas sont ainsi sélectifs pour certaines espèces de poissons telles que les cichlidés, qui représentent près de $95 \%$ de l'abondance numérique totale et contribuent à près de $90 \%$ de la biomasse totale des poissons capturés dans les acadjas. Ainsi la densité élevée des acadjas pourrait contribuer à la réduction de la richesse spécifique des poissons. La gestion rationnelle consisterait en la réorganisation de la superficie du lac Nokoué tout en préservant des zones du lac où les acadjas seraient interdits pour les espèces de poissons ne colonisant pas les acadjas.

\section{INTRODUCTION}

The "acadja" method was spontaneously initiated by fishermen in the lagoons of Benin, more than 100 years ago. The original aim was to replace the mangrove, which was known to contribute to fish production, but was disappearing due to consumption of wood by riparian human populations (Welcomme, 1971). Acadjas, therefore, function as a natural system of enhancing fish production by providing, through branches fixed on the bottom of the lake, additional substrata for development of plants and animals which will serve as food for fish. Similar fish aggregation devices, with different local names, are found in many parts of the world such as Sri Lanka (Amarasinghe et al., 2002) and Bangladesh (Ahmed and Hambrey, 1999). The major advantage of these devices is that the fish yield per unit area is much higher than in open water (Welcomme, 2002). The mode of operation of acadjas may be more complex, as it can contribute to the overall production of the water body in which it is found by increasing reproduction (see Lalèyè et al., 1995a, 1995b; Welcomme, 2002), fry survival, shelter for adults and, when properly managed, overall recruitment to fishery in general. Despite their widespread use, their high yields, and the social and environmental contention surrounding them, acadja systems have been little studied (Welcomme, 2002).

Thus, in Benin, information about acadjas concerns particularly production, evolution of number and surface of acadjas, socioeconomic and environmental aspects, and technical and social dimensions of their management (Lalèyè et al., 1995a, 1995b; Aglinglo, 1998; Welcomme, 2002). Welcomme (2002) noticed that in most cases, observations and studies of brush park fisheries have appeared in local governmental reports rather than in the wider scientific literature. Acadjas happened recently to cover a maximum of $35 \%$ of the total area of Lake Nokoué. They contribute about $40 \%$ of the island water catches in Benin. Sarotherodon melanotheron and Chrysichthys spp. are the most abundant populations in acadjas. According to Welcomme (2002), catches in brush parks in other West African coastal lagoons are similarly biased towards cichlids, S. melanotheron in particular. If the main fish species colonizing acadjas are known, little is known about all of the fish fauna and its assemblage in acadjas. The multiple uses of inland waters require knowledge of the possible impacts of exploitation on fish community attributes such as species richness, diversity and reproduction (Welcomme, 1975 in Welcomme, 2002). Fishery management also requires the knowledge of both resources and their response to the different modes of exploitation. This study aims to evaluate the impact of acadjas considered as a fishing practice on fish assemblages and on conservation of the fish fauna diversity in Lake Nokoué in Benin. 


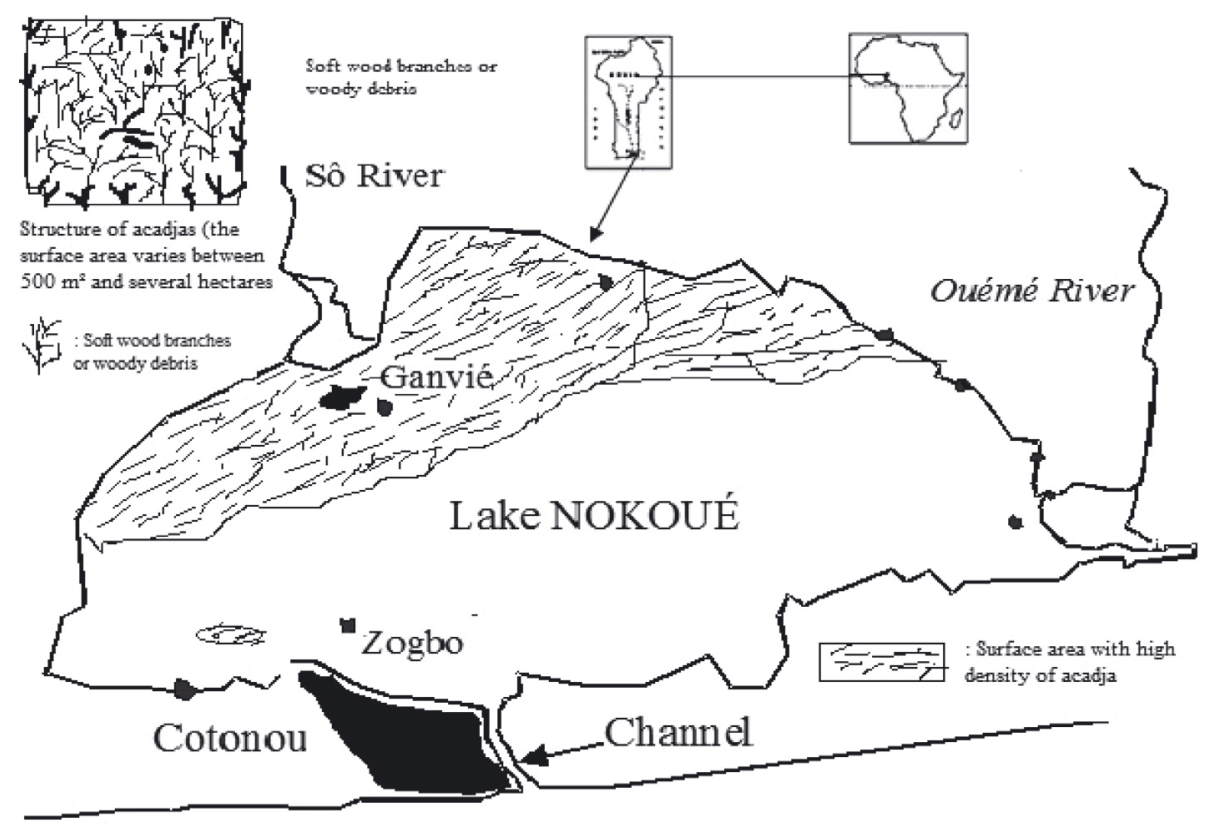

Atlantic Ocean

Figure 1

Map of Lake Nokoué, showing the two sampling stations.

Figure 1

Carte du Lac Nokoué, montrant les deux stations d'échantillonnage.

\section{MATERIALS AND METHODS}

\section{> STUDY AREA AND SAMPLING SITES}

Lake Nokoué $\left(6^{\circ} 25^{\prime} \mathrm{N}, 2^{\circ} 36^{\prime} \mathrm{N}\right.$, Figure 1 ) is the largest (approximately $150 \mathrm{~km}^{2}$ at low level) and most productive brackish water body in Benin (Lalèyè and Moreau, 2004). It is linked eastwards with Porto-Novo lagoon $\left(30 \mathrm{~km}^{2}\right)$ via the 5-km-long Totchè channel. In the north lies a vast area of $1000-9000 \mathrm{~km}^{2}$ according to the season, which is inundated every year by the floodwaters of the Ouémé Delta, whereas in the south the lake receives seawater through the 4.5-km-long Cotonou channel. Because of its location in the most densely populated part of the country, this lake has suffered since the early 1960s from major disturbances which have radically affected its ecology, notably its hydrology and salinity (Welcomme, 1972). The lake is shallow, between 0.4 and $3.4 \mathrm{~m}$ deep, with an annual average of $1.20 \mathrm{~m}$. For the purpose of this study, two stations (Zogbo and Ganvié) were identified (Figure 1). They have already been used in the past for various studies (Lalèyè, 1995; Lalèye et al., 2003). With an annual average water depth of $1.5 \mathrm{~m} \pm 0.14$, the Zogbo area is located in the south of the lake and is partly influenced by Atlantic Ocean waters (salinity slightly higher than in the Ganvié area is recorded). Only very scarce acadjas are operated in this part of the lake. The Ganvie area (annual average water depth of $1.1 \mathrm{~m} \pm 0.14$ ) is located near the floating village of Ganvié (25000 inhabitants), where the water is characterized by a high level of organic pollution (Lalèyè et al., 2003; Niyonkuru et al., 2003) and an extremely high density of acadjas.

\section{> CONSTRUCTION AND MONITORING OF EXPERIMENTAL ACADJAS}

In June 2003, two experimental acadjas were installed in Zogbo and Ganvié stations (see above). They were of rectangular form with $925 \mathrm{~m}^{2}$ of surface area each. Several types of branches were used, harder ones to surround and shape the structure and softer elements 
to fill it. The main wood species used in the construction were Dalium guineensis, Uvaria chamae, Acacia auriculiformis, Albizia adianthifolia, A. zygia, Zanthoxylon xanthoxyloides, Azadirachta indica, Mangifera indica, Anacardium occidentale, Citrus sp., Tectona grandis and Bambousa vulgaris. Certain species used in the past were not utilized because they became rare, such as Rauvolfia vomitoria, Phyllantus discoideus, Lonchocarpus sericeus and Millettia thonningü. After being cut, branches were dried for two weeks and then soaked before they were finally used to reduce their buoyancy. During the installation, some branches were driven into the mud by the fishermen who plunged into the water, and others were simply deposited into the water. At the end of the installation, the parks were enclosed with long branches of high diameter of Bambousa vulgaris to protect the acadjas against the wind and possible pillaging. To avoid possible fishing near experimental acadjas, a second wooden fence of very hard teak was built. It is important to note that these acadjas were built by the fishermen on the model of those that they usually build for themselves. After installation, the experimental acadjas were monitored from June 2003 to September 2004. The first exploitation took place six months after the installations (the necessary time for branch decomposition and their colonization by microorganisms and fishes), and then one artisanal exploitation was operated every three months in each station. So, in each of the two stations four exploitations were operated during the months of March, June, September and December, covering all seasons.

\section{> FISH SAMPLING WITHIN AND WITHOUT ARTISANAL ACADJAS}

From June 2003 to December 2004 fish samples were also obtained from the two areas within and without acadjas with the assistance of fishermen, who used gill nets, cast nets, scoop nets, long lines and the so-called "Mêdokpokonou", a locally-designed small-mesh trap net. All these gears were used throughout the year to catch all species of fish indiscriminately.

\section{> MONITORING OF THE PHYSICO-CHEMICAL AND ECOLOGICAL PARAMETERS}

Physico-chemical parameters (temperature, dissolved oxygen, $\mathrm{pH}$ and salinity) were measured inside and outside of experimental acadjas (in the surface water and at a depth of $1 \mathrm{~m}$ ). The salinity in $\mathrm{g} \cdot \mathrm{L}^{-1}$ was measured using a WTW 197 conductivity meter (salinity and conductivity), the water temperature in ${ }^{\circ} \mathrm{C}$ and the dissolved oxygen $\left(\mathrm{mg} \cdot \mathrm{L}^{-1}\right)$ were measured with an oxythermometer, and an EP-3pH meter was used for the measurement of $\mathrm{pH}$. Transparency and depth in $\mathrm{cm}$ were also measured using a Secchi disc. With the aim of seeing if acadja systems could influence some parameters such as the water $\mathrm{pH}$ and dissolved oxygen concentration, a cycle of $24 \mathrm{~h}$ of data collection (every three hours) was organized during March, corresponding to the dry season in Benin.

\section{> PROCESSING OF BIOLOGICAL DATA}

For the duration of the study, fishes collected from acadjas and from artisanal fishermen were identified by using Lévêque et al.'s (1990-1992) keys and measured to the millimeter from below the tip of snout, mouth closed, to the tip of the longest caudal fin, i.e., total length. For data processing, the software packages Statistica (Statsoft Inc. Version 5.0) and Excel were used. To investigate the organization of the fish communities the following indices were calculated and their variations analyzed.

The Shannon diversity index $H^{\prime}=\sum_{i=1}^{s} p_{i} \log _{2} p_{i}$ with $p_{i}=n_{i} / N_{i}$, where $N$ is the total number of individuals for all the species; $n_{i}$ is the number of individuals per species; and $p_{i}$ is the relative abundance of each species (Shannon, 1948, cited by Legendre and Legendre, 1984). Generally, $1<H^{\prime}<4.7$ bits; exceptionally more for species of greater sizes. 
The Piélou equitability index $(E)$ (Piélou, 1975) or index of regularity, is defined as the ratio of real diversity to maximum diversity:

$$
E=\frac{H^{\prime}}{\log _{2} S}
$$

where $S$ is species richness (number of species), $H^{\prime}$ indicates the degree of community organization and $E$ the quality of that organization $(0<E<1)$. When $E$ is close to 1 , the community structures show for different species their progressive adaptations to constraints resulting from their environment, biotic and abiotic.

Two-way analysis of variance was performed to investigate the variations in species richness in acadjas according to stations and months sampled. Here, there were two levels for stations and four levels for months. Analysis of the variations in the species richness per station and month was performed using the ANOVA test.

\section{RESULTS}

\section{> PHYSICO-CHEMICAL AND ECOLOGICAL PARAMETERS}

Measurements taken between June and December 2003 did not show significant differences inside and outside acadjas and are similar to those obtained during recent studies (Lalèyè et al., 2003). Temperature varied between $25.2^{\circ} \mathrm{C}$ and $33.1^{\circ} \mathrm{C}$ (monthly average: $27.9^{\circ} \mathrm{C}$ ) at the surface and between $25.3^{\circ} \mathrm{C}$ and $30.2{ }^{\circ} \mathrm{C}$ (monthly average: $27.6{ }^{\circ} \mathrm{C}$ ) at a depth of $1 \mathrm{~m}$; depth and transparency varied, respectively, from $0.9 \mathrm{~m}$ to $1.8 \mathrm{~m}$ (average: $1.25 \mathrm{~m}$ ) and $0.23 \mathrm{~cm}$ to $0.84 \mathrm{~m}$ (average: $0.51 \mathrm{~m}$ ); salinity varied greatly during the year: $0.0-31.4 \mathrm{~g} \cdot \mathrm{L}^{-1}$ at the surface (average: $13.3 \mathrm{~g} \cdot \mathrm{L}^{-1}$ ) and $0.0-31.5 \mathrm{~g} \cdot \mathrm{L}^{-1}$ at a depth of $1 \mathrm{~m}$ (average: $18.3 \mathrm{~g} \cdot \mathrm{L}^{-1}$ ). Salinity varied a lot according to the stations. The highest salinity was observed in Zogbo station (close to the sea) and the lowest value was observed near Ganvié (close to the River Sô). Dissolved oxygen varied from $0.54 \mathrm{mg} \cdot \mathrm{L}^{-1}$ to $7.7 \mathrm{mg} \cdot \mathrm{L}^{-1}$ (average: $3.62 \mathrm{mg} \cdot \mathrm{L}^{-1}$ ) in surface water and $0.07 \mathrm{mg} \cdot \mathrm{L}^{-1}$ to $6.23 \mathrm{mg} \cdot \mathrm{L}^{-1}$ (average: $3.13 \mathrm{mg} \cdot \mathrm{L}^{-1}$ ) at a depth of $1 \mathrm{~m}$. The lowest content of dissolved oxygen was observed in the station of Ganvié. The dissolved oxygen values measured during a 24-h cycle showed highly significant variations (ANOVA test, $p<0.05$ ) in the water inside and outside acadjas on one hand, and at the surface and in deep water, on the other hand. In general, the oxygen concentration decreases until reaching the minimum values between 1 a.m. and 7 a.m. in the morning and high values are observed after that. For the same period, the Fisher PLSD test at a significance level of $5 \%$ showed that dissolved oxygen contents were significantly different $(p<0.05)$ for various measurements, with higher values outside than inside acadjas, on one hand, and at the surface of the water in both cases, on the other hand. The variation in dissolved oxygen is presented in Figure 2. The $\mathrm{pH}$ varied from 6.5 to 8.4 in surface water and 7 to 8 at a depth of $1 \mathrm{~m}$. The ANOVA test and Fisher's PLSD test at a significance level of $5 \%$ of the $\mathrm{pH}$ values measured during a 24-h cycle showed the same daily variations $(p<0.05)$ as dissolved oxygen. The variation in $\mathrm{pH}$ is presented in Figure 3.

\section{> COMPOSITION OF THE FISH FAUNA AND FISH ASSEMBLAGES IN ACADJAS}

Twenty-five species belonging to 17 families (Table I) were identified in the acadjas. For Lake Nokoué in general, Lalèyè et al. (2003) reported 51 species belonging to 34 families. In the acadjas of Ganvié station, specific richness varied from 3 to 11 species (average: $6 \pm 3$ ) with the minimum in June and the maximum in December, whereas the richness varied from 9 to 13 species (average: $11 \pm 2$ ) with the minimum in June and the maximum in March in the acadjas of Zogbo Station. The fish fauna species identified in the acadjas belong to three main components (Figure 4):

- Seven species (28\% of the specific richness) were freshwater (Erpetoichthys calabaricus, Clarias gariepinus, Clarias ebriensis, Brienomyrus niger, Hepsetus odoe, Schilbe intermedius and Hemichromis bimaculatus). They were drained with the floods of the Ouémé River 
- $-\mathrm{O}_{2}$ in surface $\left(\mathrm{mg} \cdot \mathrm{L}^{-1}\right)$ inside of acadja

$\longrightarrow \mathrm{O}_{2}$ in depth $\left(\mathrm{mg} \cdot \mathrm{L}^{-1}\right)$ inside of acadja

$\Delta-\mathrm{O}_{2}$ in surface $\left(\mathrm{mg} \cdot \mathrm{L}^{-1}\right)$ outside of acadja

$-\times-\mathrm{O}_{2}$ in depth $\left(\mathrm{mg} \cdot \mathrm{L}^{-1}\right)$ outside of acadja

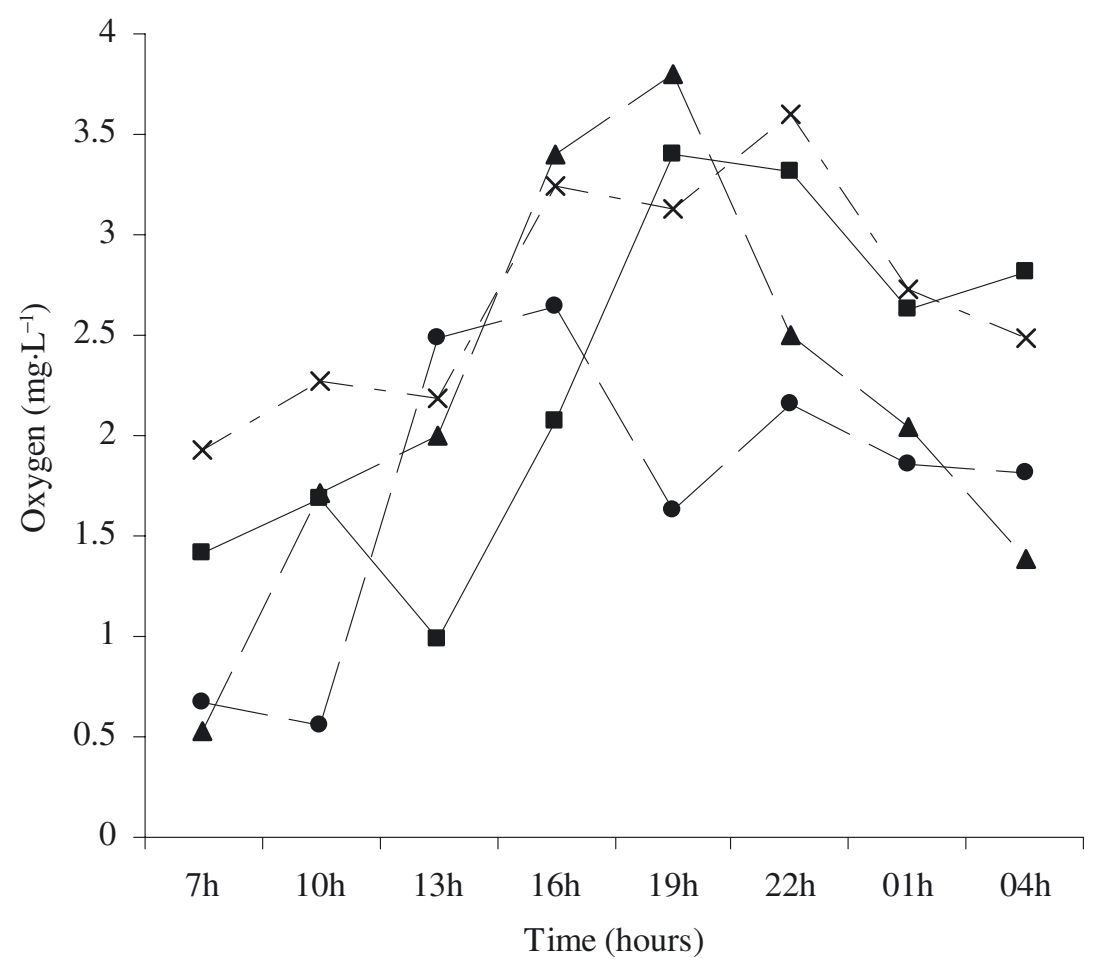

Figure 2

Daily variations in dissolved oxygen in Ganvié station outside and inside acadjas.

Figure 2

Variations journalières de l'oxygène dissous dans la station de Ganvié, à l'extérieur et à l'intérieur des acadjas.

and were observed only in the acadjas of Ganvié station, close to the mouth, only once in December at a salinity of $5 \%$.

- Four species (16\% of the specific richness) were estuarine-marine forms (Liza falcipinnis, Lutjanus goreensis, Monodactylus seba and Pomadasys jubelini).

- Fourteen species (56\% of the specific richness) were estuarine and represented about $78 \%$ of all estuarine species of Lake Nokoué identified in 2001 (Lalèyè et al., 2003).

The temporal evolution of the specific richness in the acadjas of the different stations is presented in Figure 5. From March to September, specific richness evolved in the same way in the two stations, with a high specific richness in the acadjas of Zogbo station. However, in December, specific richness was high in Ganvié station close to the Ouémé River because there were still inland fish species which arrived with the great floods of November. The ANOVA test showed that specific richness in the acadjas of Zogbo station was significantly different from the specific richness in the acadjas of Ganvié station $(p<0.05)$. Indeed, among $56 \%$ of estuarine forms identified in the experimental acadjas, $36 \%$ are common to the acadjas of the two stations. They are Sarotherodon melanotheron, Hemichromis fasciatus, Tilapia guineensis, Eleotris vittata and Chrysichthys nigrodigitatus. Twenty-one percent were fished exclusively in the acadjas of the Ganvie station: Eleotris senegalensis, Dormitator lebretonis and Bathygobius soporator. Finally, $43 \%$ were fished exclusively in the acadjas 
C. Niyonkuru and P.A. Lalèyè: Knowl. Managt. Aquatic Ecosyst. (2010) 399, 05

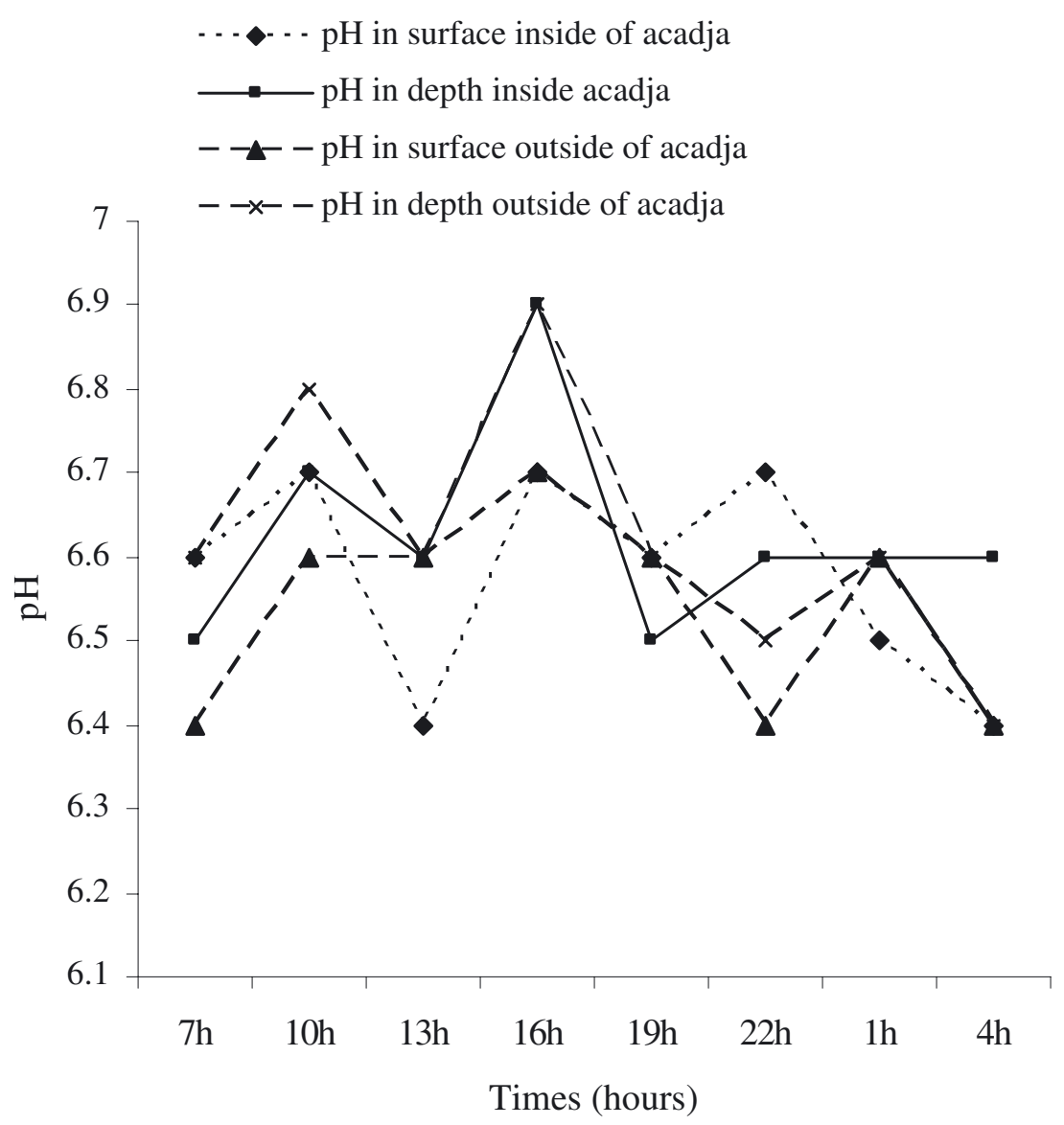

Figure 3

Daily variations in $\mathrm{pH}$ in Ganvié station inside and outside acadjas.

Figure 3

Variations journalières du pH dans la station de Ganvié à l'extérieur et à l'intérieur des acadjas.

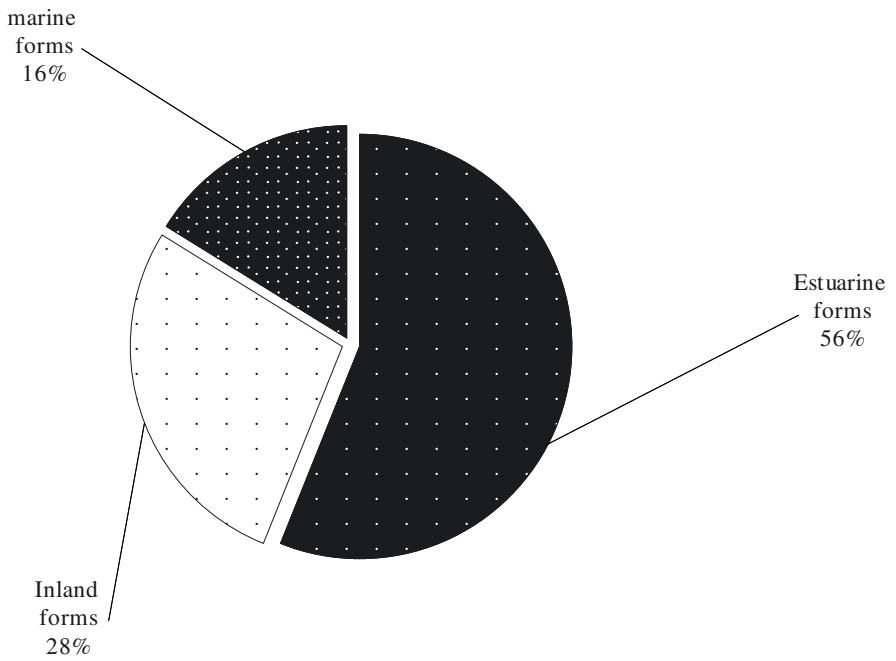

Figure 4

Main components of fish species caught in acadjas.

Figure 4

Principales composantes des espèces de poissons pêchés dans les acadjas. 


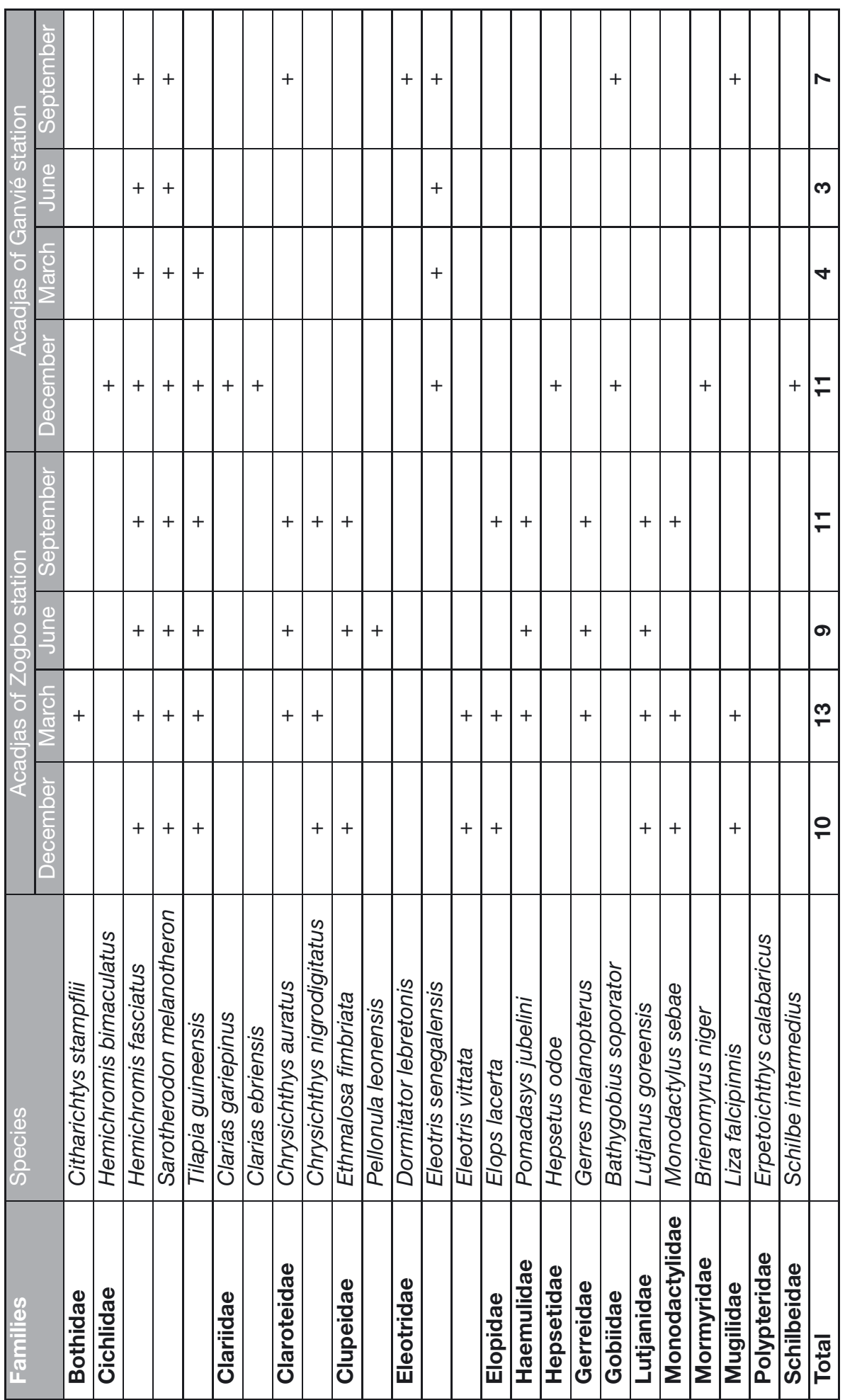

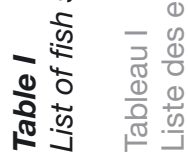




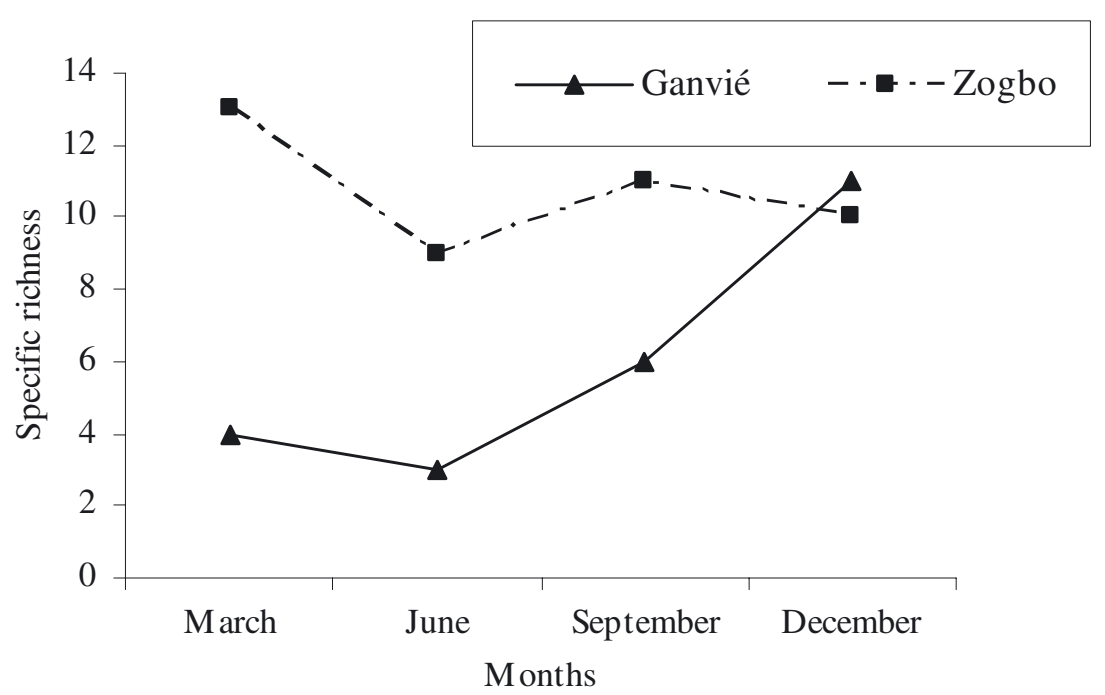

\section{Figure 5}

Evolution of the specific richness in the acadjas of the two stations.

\section{Figure 5}

Évolution de la richesse spécifique dans les acadjas des deux stations.

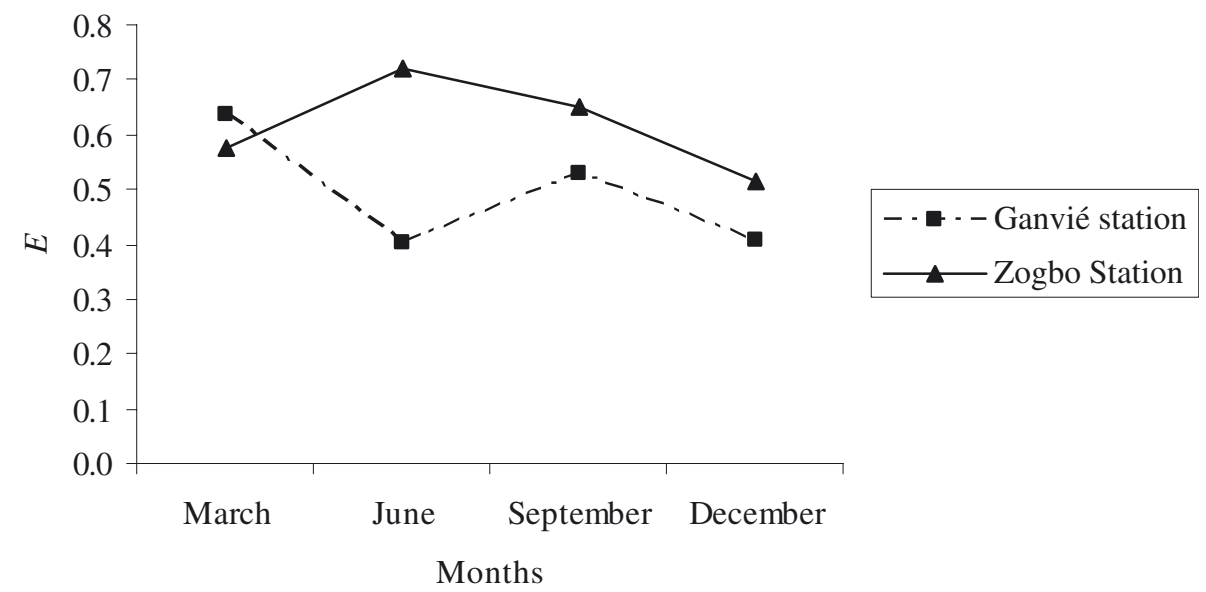

\section{Figure 6}

Evolution of the Piélou equitability index in the acadjas of Ganvié and Zogbo stations.

\section{Figure 6}

Évolution de l'indice de l'équitabilité de Piélou dans les acadjas des stations de Ganvié et Zogbo.

of Zogbo station. Among estuarine-marine forms, only one species, Liza falcipinnis, was found in the acadjas of Ganvié station, while four were found (Liza falcipinnis, Lutjanus goreensis, Pomadasys jubelini, Monodactylus seba) in the acadjas of Zogbo.

The average Shannon diversity indices were 0.94 with a variation coefficient (VC) of $4.3 \%$, and 1.45 with a VC of $12.7 \%$ in the acadjas of Ganvié and Zogbo stations, respectively. The average Piélou equitability indices were 0.49 with a VC of $22.6 \%$, and 0.61 with a VC of $14.5 \%$ in the acadjas of Ganvié and Zogbo stations, respectively. Figure 6 presents the temporal evolution of the Piélou equitability index in the two stations. Different ANOVA tests of $H^{\prime}$ and $E$ between stations on one hand, and between months on the other hand, showed significant differences $(p<0.05)$. 


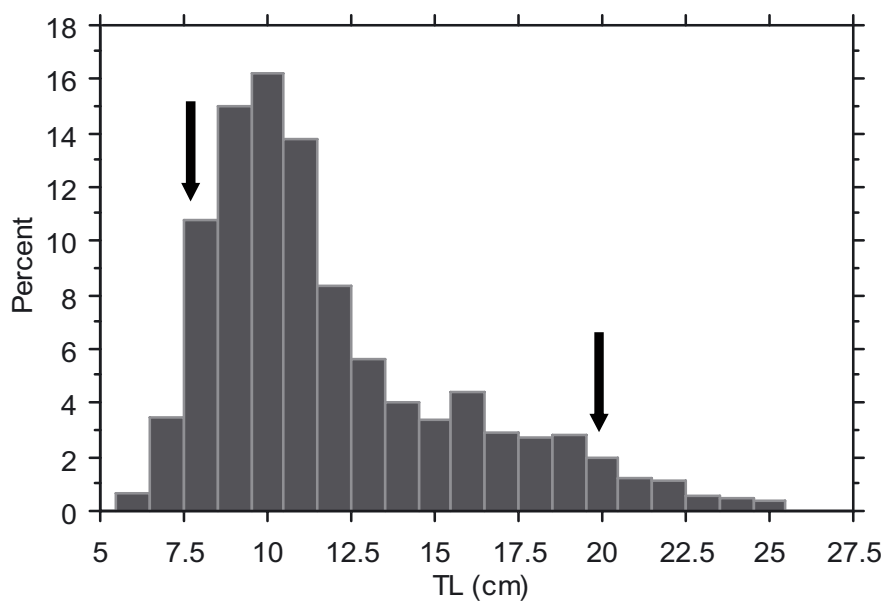

(a)

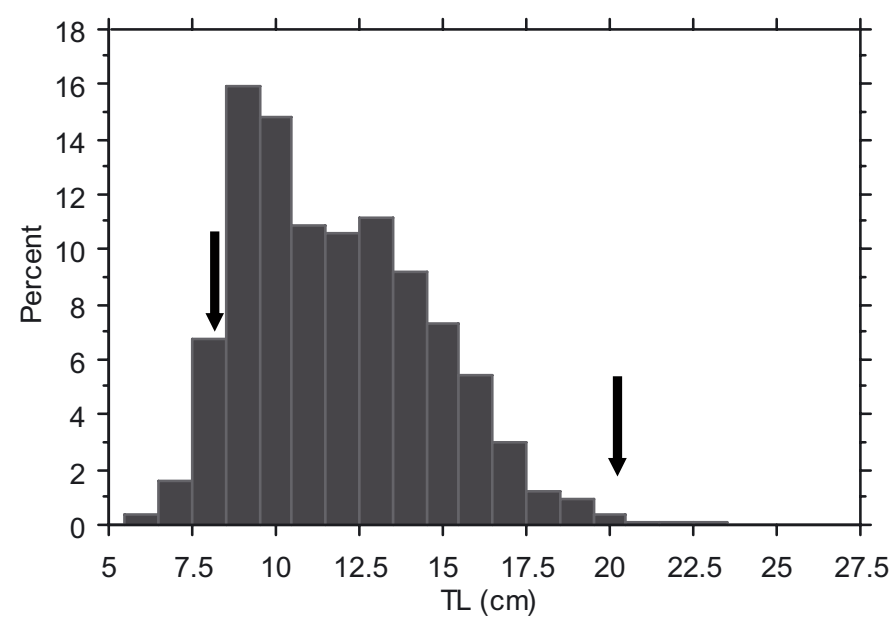

(b)

Figure 7

Length-frequency distributions of fish caught inside (a) and outside (b) acadjas. (On the left, vertical arrows indicate that there are many more individuals with sizes lower than the size of first sexual maturity inside (a) than outside (b) acadjas. On the right, vertical arrows indicate that there are many more individuals of more than $20 \mathrm{~cm}$ TL inside (a) than outside (b) acadjas.)

\section{Figure 7}

Les distributions des fréquences des tailles des poissons pêchés à l'intérieur (a) et à l'extérieur (b) des acadjas. (À gauche, les flèches verticales indiquent qu'il y a beaucoup plus d'individus avec des tailles plus petites que la taille de première maturité sexuelle à l'intérieur des acadjas (a) qu'à l'extérieur (b). À droite, les flèches verticales indiquent que l'on a beaucoup plus d'individus de plus de $20 \mathrm{~cm}$ de la longueur totale à l'intérieur des acadjas (a) qu'à l'extérieur (b).)

\section{> LENGTH FREQUENCY DATA AND ABUNDANCE ANALYSIS OF THE ACADJA FISH FAUNA}

The global length-frequency distribution of cichlids sampled within acadjas (Figure 7a) and without acadjas (Figure $7 \mathrm{~b}$ ) showed that more than $60 \%$ of the individuals measured less than $12 \mathrm{~cm}$ total length. Figure 7 also shows that inside acadjas about $5 \%$ of individuals could reach $20 \mathrm{~cm}$ TL, with the maximum size observed $25 \mathrm{~cm}$ TL, whereas fish sizes caught outside acadjas rarely exceeded $20 \mathrm{~cm}$ TL. Figures 8 and 9 introduce length frequency distributions within and without acadjas for tilapiine fishes and $H$. fasciatus, respectively, because as mentioned above, they were the main fish species caught in the acadja fisheries. The analysis of these two figures shows that in both cases, there are more juveniles inside than outside 


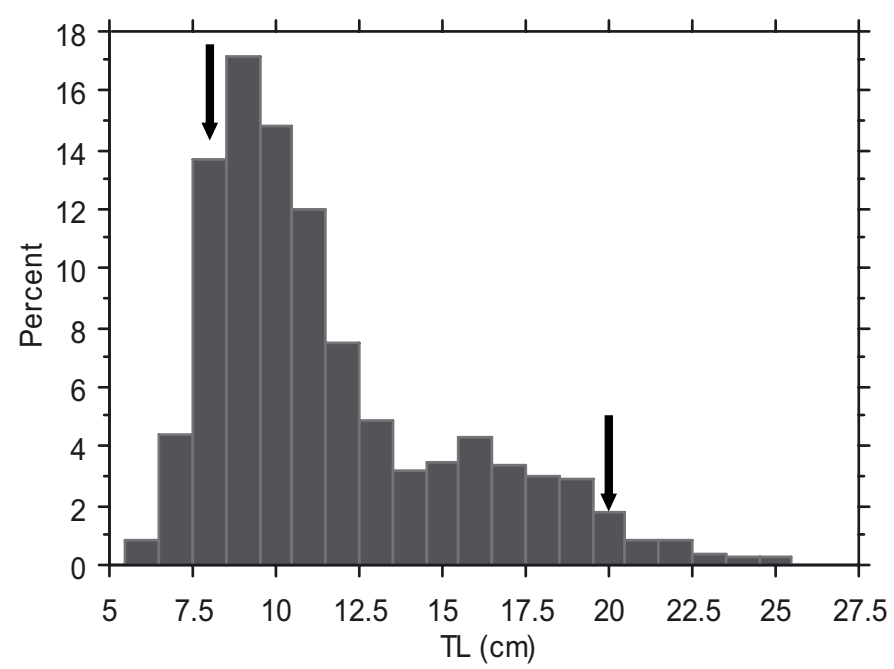

(a)

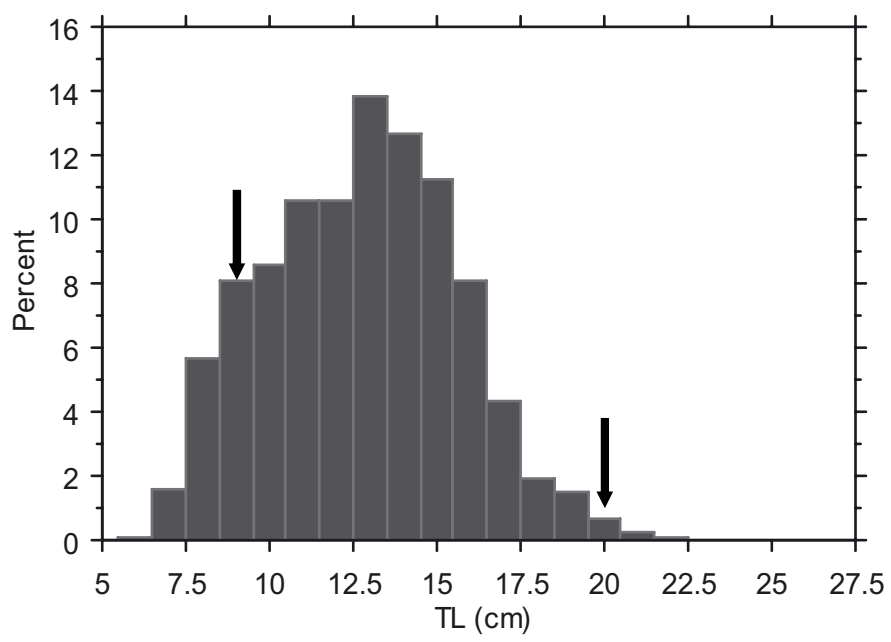

(b)

\section{Figure 8}

Length-frequency distributions of tilapiine fishes caught inside (a) and outside (b) acadjas. (On the left, vertical arrows indicate that there are many more individuals with sizes lower than the size of first sexual maturity inside (a) than outside (b) acadjas. On the right, vertical arrows indicate that there are many more individuals of more than $20 \mathrm{~cm}$ TL inside (a) than outside (b) acadjas.)

\section{Figure 8}

Les distributions des fréquences des tailles des poissons tilapias à l'intérieur (a) et à l'extérieur (b) des acadjas. (À gauche, les flèches verticales indiquent qu'il y a beaucoup plus d'individus avec des tailles plus petites que la taille de première maturité sexuelle à l'intérieur des acadjas (a) qu'à l'extérieur (b). À droite, les flèches verticales indiquent que l'on a beaucoup plus d'individus de plus de $20 \mathrm{~cm}$ de la longueur totale à l'intérieur des acadjas (a) qu'à l'extérieur (b).)

the acadjas and individuals of greater size are observed inside than outside acadjas: about $25 \mathrm{~cm}$ TL and $20 \mathrm{~cm}$ TL, respectively, for tilapiine fishes and about $16.5 \mathrm{~cm}$ TL and $16.5 \mathrm{~cm}$ $T L$, respectively, for $H$. fasciatus. Moreover, the relative abundances in numbers and biomass of the main fish species caught inside the acadjas are presented in Figure 10 . Cichlids $(95 \%$ of the total numeric abundance) contribute about $90 \%$ of the total fish biomass of the acadjas. Sarotherodon melanotheron represents $87 \%$ of the commercial production of the acadjas of Lake Nokoué. Hemichromis fasciatus and Tilapia guineensis represent, respectively, $6 \%$ and $2.5 \%$ of the total biomass fished in the acadjas. In Ganvié station, cichlids represent more 


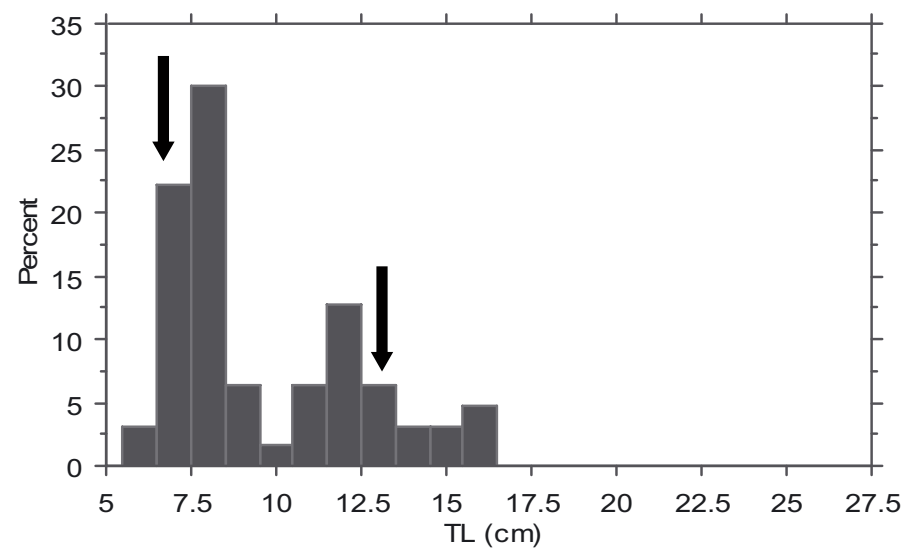

(a)

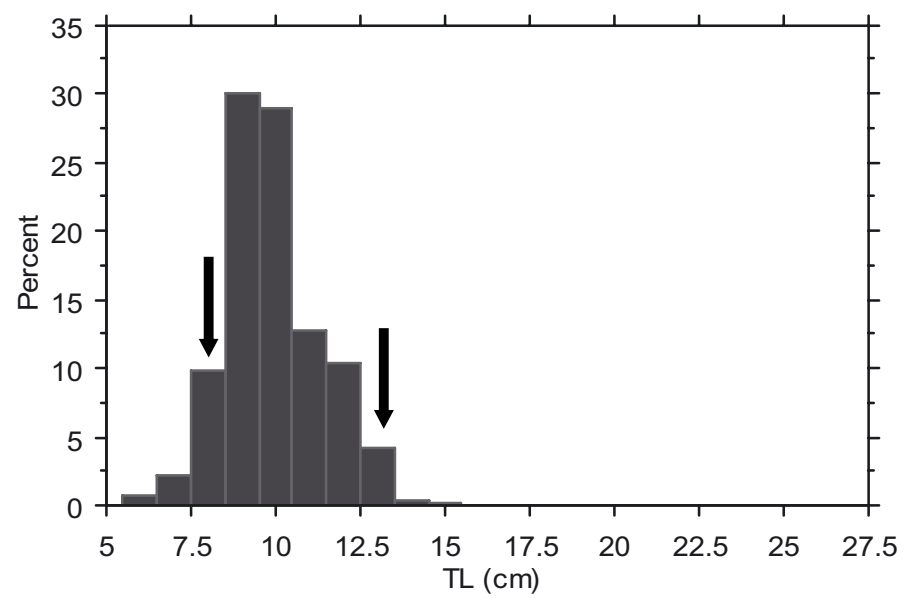

(b)

\section{Figure 9}

Length-frequency distributions of $\mathrm{H}$. fasciatus caught inside (a) and outside (b) acadjas. (On the left, vertical arrows indicate that there are many more individuals with sizes lower than the size of first sexual maturity inside (a) than outside (b) acadjas. On the right, vertical arrows indicate that there are many more individuals of more than $12.5 \mathrm{~cm}$ TL inside (a) than outside (b) acadjas.)

\section{Figure 9}

Les distributions des fréquences des tailles des poissons de $H$. fasciatus pêchés à l'intérieur (a) et à l'extérieur (b) des acadjas. (À gauche, les flèches verticales indiquent qu'il y a beaucoup plus d'individus avec des tailles plus petites que la taille de première maturité sexuelle à l'intérieur des acadjas (a) qu'à l'extérieur (b). À droite, les flèches verticales indiquent que l'on a beaucoup plus d'individus de plus de 12,5 cm de longueur totale à l'intérieur des acadjas (a) qu'à l'extérieur (b).

than $96 \%$, against $89 \%$ in Zogbo station. Sarotherodon melanotheron $76 \%$ in Ganvié and $42 \%$ in Zogbo) and Hemichromis fasciatus (19\% in Ganvié and $41 \%$ in Zogbo) are widely represented. Other species of commercial importance fished in the acadjas are Chrysichthys nigrodigitatus and $C$. auratus, which represent about $2 \%$ of the total fish biomass in the acadjas.

\section{DISCUSSION}

The results of the present study show that acadjas constitute a particular environment which is favorable for certain fish species and unfavorable for others. According to Welcomme (2002), brush parks are generally selected by certain species, particularly Chinese carps in Asia 


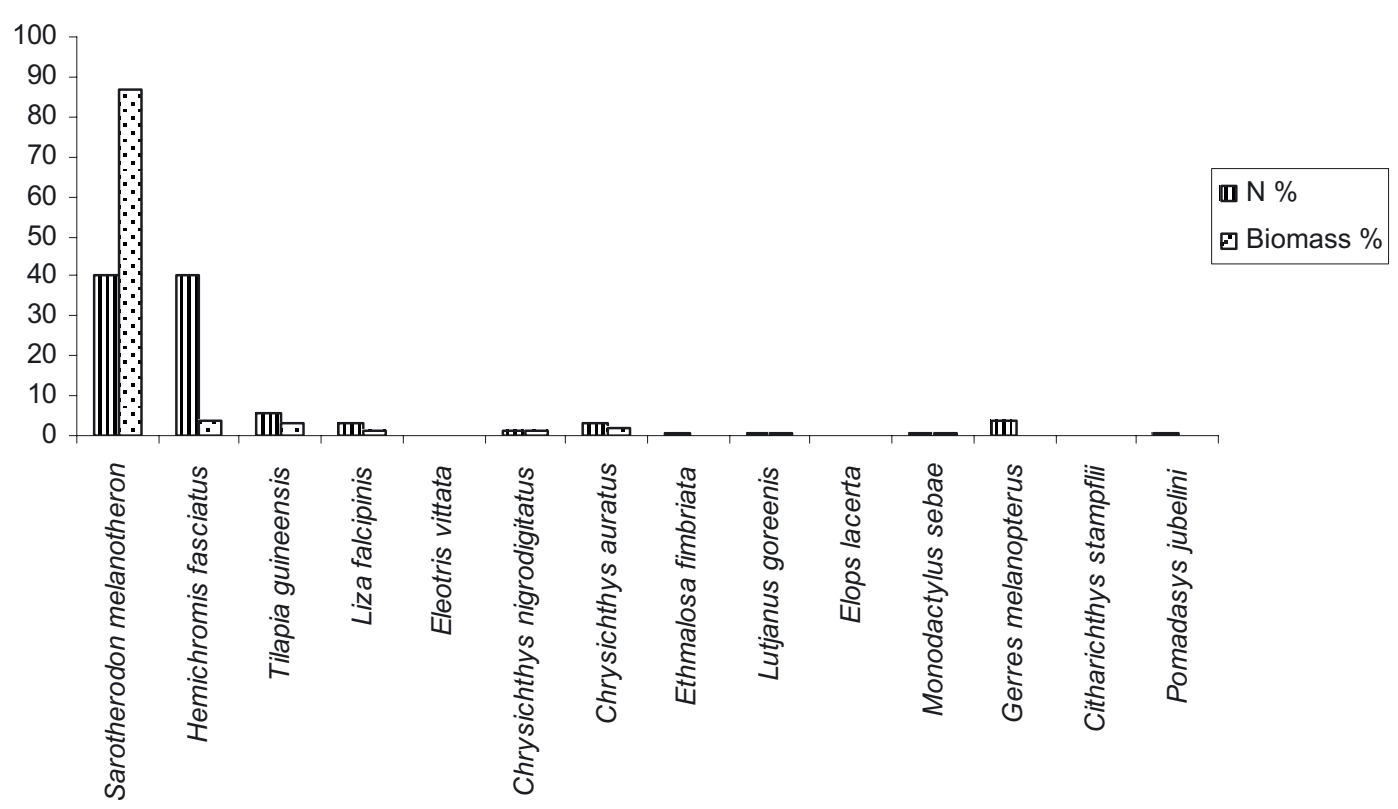

Figure 10

Relative abundance in numbers and biomass of fish species caught in experimental acadjas during this study.

\section{Figure 10 \\ Abondance relative numérique et pondérale des espèces de poissons pêchés dans les acadjas expéri- mentaux au cours de la présente étude.}

and cichlids in Africa and Sri Lanka. He showed that two species (Sarotherodon melanotheron and C. nigrodigitatus, 72.6 and $23.8 \%$ of the catch, respectively) were dominant in the brush parks of Lake Nokoué in 1969-1970. In the present study, Chrysichthys nigrodigitatus were absent in the acadjas of Ganvié station and uncommon in the acadjas of Zogbo station. Indeed, different factors govern specific diversity in estuaries or lagoons; among them are habitat diversity and repopulation potential. Other interdependent factors are mentioned by different authors such as Whitfield et al. (1981), Whitfield (1988), Lévêque (1994), Albaret and Diouf (1994), and Lalèyè et al. (2003): physico-chemical characteristics and their spatial and temporal variations, trophic richness and availability of resources, the presence and situation of the mangrove swamp, human interventions, organization of communications with the ocean, and fishing activities. For instance, concerning some physico-chemical characteristics such as water $\mathrm{pH}$ and dissolved oxygen, the results obtained in the present study showed that, for the same period, the Fisher PLSD test at a significance level of $5 \%$ showed significant differences $(p<0.05)$ for various measurements outside and inside acadjas, with higher values outside than inside acadjas. Also, due to the decomposition of organic matter of acadja systems, the water $\mathrm{pH}$ and dissolved oxygen values were significantly different $(p<0.05)$ between the water surface and deep water, with high values at the water's surface. So, acadja systems modify physico-chemical and ecological characteristics, meaning that these variations could significantly influence fish assemblages. Assemblages of fish are extremely diverse in terms of habitat selection, and reproductive and trophic behavior. Considering the responses of multi-species groupings to stress, one of the major factors is the trophic nature of the species, and more particularly, the importance of predation behavior (Welcomme, 1999). Brush parks attract species that are normally associated with naturally occurring vegetation and large woody debris in the rivers, floodplain lakes and lagoons (Welcomme, 2002). It is the case of most species widely represented in the acadjas during the present study.

Moreover, it is important to note the differences in the Piélou equitability index in the acadjas of the two stations, with a high value in Zogbo station. According to Albaret et al. (1982) 
cited by Albaret (1994), the community structures indicate for different species more progressive adaptations to constraints resulting from their biotic and abiotic environment than in the acadjas of Ganvié station, which has higher density of acadjas than Zogbo station.

The poor specific richness and the low values of the Shannon and Piélou equitability indices observed in the acadjas of Ganvié station could be explained by the significant organic pollution due to the density of acadjas and to the presence of the lakeside village of Ganvié. Obstructions to flow caused by large masses of brush placed in the water can slow currents locally to a point where deposition of silt is accelerated. In these conditions, immediate consequences of the decomposition of branches deposited in the water are eutrophization with dissolved oxygen rate reduction, particularly during the night, as was observed during the $24 \mathrm{~h}$ cycle carried out in the present study. Fish species which are unable to withstand these new environmental conditions are constrained to move somewhere else.

In the present study, more than $60 \%$ of the individuals had less than $12 \mathrm{~cm}$ total length, and $30 \%$ of them had sizes lower than the size of first maturity (i.e. $9 \mathrm{~cm}$ total length) observed for Sarotherodon melanotheron, the most abundant fish species in acadjas (Niyonkuru, 2007). This predominance of young individuals could indicate that acadjas offer favorable conditions of breeding for some fish species at the same time as providing food to larvae and juveniles and thus assuring the role of nurseries. Indeed, the young fishes find there abundant and diversified food (plankton, periphyton and other invertebrates) which develop on surface immersed branches and on the bottom of the lake, enriched by the decomposition of the wood. The food is available there at any time. As shown by some authors (Welcomme, 2002; Lalèyè et al., 2003), acadjas can be regarded as traditional fish farming in Benin and in West African regions. Indeed, for fish species such as tilapiines, which easily colonize acadjas, this study showed that individuals could very scarcely reach the large sizes usually observed in lagoons (25 cm TL) where acadjas are scarce. This means that if acadjas are left unexploited for a long period, for instance one year, fishes are protected from fishing, ecological conditions are favorable for their reproduction and time is sufficient for their growth. Unfortunately, as was confirmed by this study, the acadja practice appears selective for some fish species and could contribute to the decrease in the fish fauna biodiversity because few species can adapt to these new conditions created by the decomposition of the branches deposited in the lake. The search for increasing yields by setting up a significant quantity of acadjas could entail a decrease in the specific richness of the whole lake. As Welcomme (1999) mentioned, it is very important to maximize yields, but while preserving fish assemblage as far as possible.

For the conservation of the fish assemblages, we invite the government to be involved more in the management of the lakeside space to avoid unregulated occupation which could entail biodiversity erosion. For better success, it is important to involve fishermen populations in the management. Another possibility of management should be to reorganize the surface areas of Lake Nokoué in order to preserve a part of the lake for other fish species for which acadjas are not favorable.

\section{ACKNOWLEDGEMENTS}

We would like to thank very sincerely the British Ecological Society (BES) and International Foundation for Science (IFS) for financing this study through their Program of Research Grants. Our thanks also go to Dr Neil Sprigante and Dr Dominic Burton, Administrators of the BES.

\section{REFERENCES}

Aglinglo A.C., 1998. Production halieutique dans les acadjas du lac Nokoué et de la lagune de PortoNovo en République du Bénin. Mémoire de D.E.S. en Sciences de la Terre et de la Vie, Université de Liège.

Ahmed K.K. and Hambrey J.B., 1999. Brush shelter: a recently introduced fishing method in Kaptai reservoir fisheries in Bangladesh. NAGA, 22, 20-23. 
Albaret J.J., 1994. Les poissons : biologie et peuplement. In: Durand J.R., Dufour P., Guiral. D. and Zabi S.G. (eds.), ORSTOM, France, Environnement et ressources aquatiques de Côte d'Ivoire, Tome II, Les milieux lagunaires, 239-279.

Albaret J.J and Diouf P.S., 1994. Diversité des poissons des lagunes et des estuaires ouest-africains. In: Teugels G.G., Guégan J.F. and Albaret J.J. (eds.), Diversité biologique des poissons d'eaux douces et saumâtres d'Afrique, Annales du Musée Royal de l'Afrique Centrale, Zoologie, 275, 165-177.

Amarasinghe U.S., Amarasinghe M.D. and Nissanka C., 2002. Investigation of the Negombo estuary (Sri Lanka) brush park fishery, with an emphasis on community-based management. Fish. Manag. Ecol., 9, 41-56.

Lalèyè P., 1995. Écologie comparée de deux espèces de Chrysichthys (Siluriformes, Claroteidae) du lac Nokoué et de la lagune de Porto-Novo au Bénin. Thèse de doctorat en sciences, Université de Liège.

Lalèyè P. and Moreau J., 2004. Resources and contains of West Africa coastal waters for fish production. In: Abban E.K., Casal C.M.V., Dugan P. and Falk T.M. (eds.), Biodiversity, Management and Utilization of West Africa Fishes, Wordfish Center Conference, Proceedings, Contribution n ${ }^{\circ} 1718$, 28-30.

Lalèyè P., Philippart J.C. and Heymans J.C., 1995a. Cycle annuel de l'indice gonadosomatique et de la condition chez deux espèces de Chrysichthys (Siluriformes, Claroteidae) du lac Nokoué et de la lagune de Porto-Novo au Bénin. Cybium, 19, 131-142.

Lalèyè P., Phillipart J.C. and Poncin P., 1995b. Biologie de la reproduction de deux espèces de Chrysichthys (Siluriformes, Claroteidae) du lac Nokoué et de la lagune de Porto-Novo au Bénin. Revue de Zoologie Africaine, 109, 213-224.

Lalèyè P., Niyonkuru C., Moreau J. and Teugels G.G., 2003. Spatial and seasonal distribution on the ichtyofauna of Lake Nokoué, Bénin, West Africa. African Journal of Aquatic Science, 28, 151-161.

Legendre L. and Legendre P., 1984. Écologie numérique, Tome 2 : La structure des données écologiques, $2^{\mathrm{e}}$ Collection d’Écologie, 13, Masson (ed.), Presses de l'Université de Québec, Canada.

Lévêque C., 1994. Biodiversité des poissons africains. In: Teugels G.G., Guégan J.-F. and Albaret J.-J. (eds.), Diversité biologique des poissons des eaux douces et saumâtres d'Afrique, Synthèses géographiques, Annales du Musée Royal de l'Afrique Centrale, Zoologie, 275.

Lévêque C., Paugy D. and Teugels G.G. (eds.) (1990-1992). Faune des poissons d'eaux douces et saumâtres de l'Afrique de l'Ouest, Éditions ORSTOM, France.

Niyonkuru C., Lalèyè P., Hounkpè C. and Moreau J., 2003. Impact de la pêche sur les ressources aquatiques des plans d'eau du sud-Bénin. In: Troisième Conférence Internationale de l'Association Pan-Africaine des Pêches, Benin, 193-194.

Niyonkuru C., 2007. Étude comparée de l'exploitation et de la démographie des poissons cichlidés dans les lacs Nokoué et Ahémé au Bénin. Thèse de Doctorat, Université d'Abomey-Calavi.

Piélou E.C., 1975. Ecological diversity, Wiley InterScience, New York.

Welcomme R.L., 1971. Évaluation de la pêche intérieure, son état actuel et les possibilités. FAO AT, 2938, Rome.

Welcomme R.L., 1972. An evaluation of the "acadjas" method of fishing as practised in the coastal lagoons of Dahomey (West Africa). J. Fish Biol. , 4, 39-55.

Welcomme R.L., 1999. A review of a model for qualitative evaluation of exploration levels in multispecies fisheries. Fish. Manag. Ecol., 6, 1-19.

Welcomme R.L., 2002. An evaluation of tropical brush and vegetation park fisheries. Fish. Manag. Ecol., 9, 175-188.

Whitfield A.K., 1988. The fish community of the Swartvlei estuary and the influence of food availability on resource utilisation. Estuaries, 11, 160-170.

Whitfield A.K., Blaber S.J.M. and Cyrus D.P., 1981. Salinities range of some southern African fish species occurring in estuaries. South African Journal of Zoology, 16, 151-155. 